\title{
CHANGE BUSINESS MODEL OF ISLAMIC RELIGIOUS COLLEGE BUSINESS IN EAST JAVA BY BUILDING INTEGRATED ONLINE POLICY AND TECHNOLOGY SYSTEMS DURING THE COVID-19 PANDEMIC PERIOD \\ Ilham ${ }^{1}$, Heri Cahyo Bagus Setiawan², Nuzulul Fatimah², Tatag Herbayu L \\ ${ }^{1,}$ System of Information Study Program, Faculty of Science and Technology, UIN Sunan Ampel of Surabaya \\ ${ }^{2}$ Entrepreneurship Study Program, Faculty of Economics and Business, University Muhammadiyah of Gresik \\ ${ }^{3}$ Institute of Economic Science Mahardhika Of Surabaya \\ ${ }^{4}$ Faculty of Economics and Business, Airlangga University, Jl. Airlangga No.4, Airlangga, 60286, Surabaya, Indonesia. \\ ${ }^{1}$ ilham@uinsby.ac.id \\ ${ }^{2}$ hericbs@umg.ac.id \\ ${ }^{3}$ nuzulul.fatimah@stiemahardhika.ac.id \\ tatag@feb.unair.ac.id
}

\begin{abstract}
This study conducted an analysis and evaluation of business services activities $\mathrm{P}$ erguruan $\mathrm{T}$ Heigh under the Ministry of Religious Affairs in $\mathrm{J}$ awa $\mathrm{T}$ imur to create a model of an integrated online system to maximize kan activities of the service business during a pandemic covid 19. Enterprises college business has expanded rapid and during the pandemic covid has made changes to the service online, after the application of social distance in an effort to deal with the spread of the disease corona virus (Covid-19). Initially, an increase in people's interest to shop online was to buy necessities of life very high with many transaction processes. The aim is to provide effective and efficient services to all business transactions conducted online during the pandemic covid19. The methodology used is a qualitative research method with case studies and using purposive samples. The analytical approach used is interpretive analysis. The results of the research show that implementing an integrated online system is able to serve many business transaction processing activities which are greatly improved. So it can be concluded several things as follows: With an integrated online system through planning and organizing business systems can illustrate the various classifications of implementation of business services online business activities in order to facilitate all forms of business transaction processes quickly, effectively and efficiently during Covid-19. System integration of online ie business opportunities using technology that can deliver greater value for the business of the college that the college of business can be developed and can be maintained as well as helping people to meet their needs and facilitate online transactions. Keyword: Business, Higher Education, Integrated online System, and Pandemic Covid19,
\end{abstract}




\section{INTRODUCTION}

\subsection{Background}

System integration of information is one of the key concepts of the stem of information management. Various stem interconnected with each other in various ways in accordance with the needs of its integration. Good, structured and reliable information technology management is an absolute necessity for educational services especially at tertiary institutions. The main objective of Information Technology governance is to reduce risk and ensure that investment in the form of information technology resources can add value to the corporation (Hall 2011). The role of significant information technology must be balanced with appropriate arrangements and management so that possible losses can be avoided. Losses in question can be in the form of inaccurate information so that it can affect the wrong decision making, the reliability of IT equipment that is not good so many complaints.

The use and function of information systems has become an important part of all types of organizations. Similarly, the development of educational services in the sector known as the Information Systems Business ( si pusbis). Business Center Information System is an absolute necessity for business services of higher education institutions, so that it can provide facilities in administration for universities that apply it for business interests. With the existence of a Business Center Information System and other Information Systems at Islamic Religious Colleges in East Java such as UIN Sunan Ampel Surabaya and UIN Malik Ibrahim Malang, not only services for students are getting better but also services for the public and all parties related to business processes businesses are conducted by universities, so it can influence the effectiveness and efficiency of the business activities and can m encapai goals and strategies of the business organization. To keep the information technology easel in enhancing the value of the business venture College of Religious Islam in East Java such as U niversitas Islam Negeri Sunan Ampel Surabaya and others, the need for information technology governance businesses that qualified for all the factors and dimensions associated with the use of information technology is synergized and can provide added value and expected return on investment for universities. The business units at UIN Sunan Ampel include airplane ticket services, Umrah agents, Greensa Hotels, UIN brand drinks, UINSA MARK, Fitness services, Building Rentals, and others. The convenience and improvement of services for stakeholders in the Islamic Religious Higher Education environment in East Javacan be continuously improved by the application of business information technology that is right on target.

The COVID-19 pandemic that hit the whole world including Indonesia not only posed a threat but also provided opportunities for a number of business sectors. One of the big opportunities in the pandemic era is business sectors related to online or online and information technology or also known as information technology . Policy observer and strategic communication from Daegu University, South Korea, Prof. Gil H. Park assesses that online or information technology-based economic activities will play a more important role in the aftermath of the COVID-19 epidemic ( Aji Cakti, 2020) .

According to him this pandemic is not just a threat but an opportunity for the service sector to be more adaptable and transformed in the economic sector, and the government needs to help more business activities and information technology-based economies. This needs to be done considering that information technology-based or online (online) economic activities will play a more important role in the future. The same opinion also came from the Ambassador of the Republic of Indonesia to South Korea Umar Hadi who said that online businesses, especially those in South Korea, would boom or increase. According to Umar Hadi, in the aftermath of the pandemic crisis that engulfed the entire online business world, it will experience very profitable moments. Then what 
online businesses will be bolted and what factors support business growth that is expected to be even greater after the Covid-19 pandemic? (Aji Cakti, 2020) .

\subsubsection{From e-commerce to edutech}

The number of sectors in the online business, making business people who want to invest need to guess what online businesses that make up for in the era of COVID-19. Entrepreneur and founder of Bahaso's startup platform, Tyovan Ari Widagdo assessed that there are a number of startup business sectors that are likely to be popular and profitable in the current pandemic era, such as e-commerce, edutech, and health.

According to Tyovan, startup business sectors precisely because of this pandemic experienced a significant increase in business where online health platforms such as Halodoc became popular because it helped the public who only wanted to consult and diagnose health online. The ecommerce business is also a major need for the public to transact during this pandemic, given that the public is afraid to shop directly so that some purchases are made online through e-commerce platforms.

Besides platforms national e-commerce business that is already established, is now also emerging platforms of local e-commerce, especially to meet the needs - a basic requirement. Young people in several cities create local e-commerce platforms to help the process of buying goods from consumers to markets. Next is the startup business Collaboration Tools such as the Zoom and GotoMeeting application, which became popular in the era of the COVID-19 pandemic. Opportunities in this sector are taken by foreign companies considering that in Indonesia alone there are still few or even no actors who take advantage of opportunities in the startup business of Collaboration Tools.

In addition, from the agriculture sector such as the TaniHub platform, it also became popular, then other startup businesses that were hockey in the Covid-19 era were education or edutech technology sectors such as Ruangguru, Zenius. Tyovan said that it was now impossible for students to study at school due to the pandemic so they studied at their homes online.

The popularity of the edutech sector will not stop in the pandemic era, given that business in this industry will continue to develop in a pandemic condition where people are forced to interact with technology ( Aji Cakti, 2020) .

\subsubsection{Work from home becomes commonplace}

One of the factors that made online businesses prosper in the pandemic era was the work, study, and worship activities from home or known as work from home (WFH) which is run by everyone in order to avoid infection. Senior Services Office Director Colliers International Indonesia (property consultant), Bagus Adikusumo estimates that work patterns from home will become more common in its application by a number of company offices due to the impact of COVID-19, and is expected to continue after the pandemic can be handled.

According to him, if this WFH continues for a long time due to the prolonged spread of the pandemic, then it will become a protocol that a company runs on its employees. In the future, WFH will become an attractive business model to be continued so that there will be various adjustments to the company's work patterns.

A similar sentiment was also conveyed by Indef's Associate Economic Researcher Muhammad Zulfikar Rakhmat who considered that when viewed from the positive side, the COVID-19 pandemic had taught all parties to how to do online activities. According to him, now everyone can learn and know how the work system, education and a number of business activities can be done online, including activities from home.

In the future there will be many people both in Indonesia and the world working and doing activities online, because the COVID-19 pandemic has opened up the insight that some activities including business can be made possible through digitalization ( Aji Cakti, 2020) . 


\subsubsection{Forced to transform online}

Another factor that needs to be examined in relation to the rapid launch of online business in this pandemic is that the disease has succeeded in forcing traditional business people, such as the University of Traditional Business College Business and food and beverage businesses, to transform into the online realm. Indef observer Andry Satrio assesses that the pandemic itself has succeeded in accelerating and even forcing business transformation, especially food and drink and selling activities from traditional to online or online through the principle of digitalization. According to Andry, currently all parties are forced to carry out online activities and apply the principle of digitalization, otherwise economic and business activities will die. Real examples, how the traditional market today inevitably have to be able to run the principle of delivery of the goods after receiving orders online or via telephone, kalua can not be lost to other competitors. At present all trading activities are carried out online and carry out the principle of delivery, especially for the restaurant sector and the food-beverage business is forced to run a business where orders can be done online. None of this transformation could have been as fast as now after the advent of the COVID-19 pandemic. Supermarkets can now serve orders via social media applications such as Whatsapp ( Aji Cakti, 2020). Departing from this explanation, universities must also transform and convert each business unit to implement an integrated online system to meet the needs of business transaction processes during the pandemic covid19, this is done to keep the business running and developing in accordance with the guidance of the community. The purpose of this research is to find out the extent of the development and strategy of higher education business units in dealing with the behavior of business users during pandemic covid19.

\section{2 Problem Formulations}

Based on the phenomena in the background of the above problems, a problem can be formulated with the Research Question as follows:

How can the integrated online system model of business ventures carried out by tertiary institutions contribute effectively and efficiently to business business services during the Covid 19 pandemic?

\subsection{Research Objectives}

This study aims to produce a model of integrated online system to perform the analysis and evaluation of the system model businesses are conducted by universities that can contribute to effective and efficient business services during a pandemic Covid 19?

\subsection{Research Benefits}

The expected benefits of the research to be carried out by the author are as follows:

a. Theoretical benefit

This study is expected to provide contributions to the development of the concept of science, especially the science of management in the field of Resource Information System, M anusia, Management, Strategy and Information Technology, Performance, Discipline, Effectiveness and Quality of Higher Education Service in East Java Islamic Religious

b. Practical benefits

The benefits to be gained from this research is $d$ iharapkan provide benefits for the management of the college as an effort to improve Business Enterprises, Human Resources, Performance, Discipline, Effectiveness and Quality of Service Business and policies relating to improved governance of Business Enterprises, Human Resources, Integrated Information Technology Strategy and Implementation. 


\section{LITERATURE REVIEW}

\subsection{Theory Review}

\section{Revolution 2.1.1 T echnology I nformation \& Control in the Age COVID-19}

Are we in the midst of a technological revolution? Yes? I feel the technological revolution should feel more empowering and exciting. It should feel like something better than something catastrophic. But if you define it as a moment when there are many technological changes that will last for years or decades, yes. Think about how health, education, work from home will change. There are many discoveries today because of the coronavirus that will be attached to us. With the increasing need for surveillance, will microchipping be something? Microchipping is where you put a little microchip into your body and you can use it to scan yourself, you can embed data in it, you can use close field identification. But no, that won't be anything because you can do all that on your phone. Insert a microchip in your cellphone. Carry a cellphone in your pocket or put it in your watch. Placing it on your skin is unnecessary and somewhat dirty

Human Resource Management is an ongoing procedure that aims to supply an organization or company with the right people to be placed in the right position and position when the organization needs it, this understanding also shows that human resource management is related to Stoner's organizational behavior (2006). The basis of this research is to improve the quality of human resources and internal services at Islamic Religious Colleges in East Java suspected of being influenced by the adoption of information systems and human resource technology, performance development, and work discipline, so it is necessary to examine the existence of individual behavior in tertiary institutions Islamic Religion in East Java . The variables in this research are service quality, performance development, work discipline, and also the implementation of HR information systems are part of the organization's human behavior, this study also discusses human behavior in the organization that is behavior in Islamic Religious Colleges in East Java .

\subsection{Understanding Information Technology}

The purpose of an Information Technology Audit is to evaluate the system's internal control design and effectiveness. Not limited to the efficiency and security of protocols, the development process, and IT governance. Control installation is very necessary, but adequate protocol security is needed so that there are no security breaches. In an Information Systems environment, an audit is an examination of information systems, inputs, outputs, and processing. The main function of this IT audit is evaluating the system to maintain the security of the organization's data. IT audits aim to evaluate and assess risk to safeguard valuable assets and establish methods to minimize those risks.

\subsection{Human Resources}

Vikas (2012) states " Human resource information system (HRIS) is an integrated system designed to provide information used in HR decision making. This means that the human resource information system is an integrated system designed to provide information used in HR decision making. Meanwhile, according to Mathis (2006), "Human resource information systems are integration systems designed to provide information needed to make human resource decisions. The statement also showed that the human resource information system was designed to support various things in human resource activities that would be related or useful in making decisions in the field of human resource management. 


\subsection{4 . Performance Development}

The human resource approach according to Davis and Newstrom, (1990: 14), is "Emphasizing attention to the growth and development of people to achieve a higher level of ability, creativity, and fulfillment, because people are the most important resources in the organization and any society. " Performance development is inseparable from the goal to improve the ability of human resources, and also the interests of the organization in improving the quality of human resources owned to be able to solve every problem that arises in the organization.

\subsection{Work Discipline}

Work discipline has an important meaning for the company with the work discipline of each employee will make the company better, because employees who are disciplined will be able to complete their tasks with high quality and appropriate time. Disciplined employees will of course comply with the applicable regulations in the organization or follow the applicable standard operating procedures, by following existing regulations and not violating the rules set by the organization it will be easier for employees to achieve improved performance .

\subsection{6 . Quality of Service}

Before explaining tenyang quality of service, the first definition of service is explained. According to Gronroos (2005) said that "Service is a series of activities that are invisible (cannot be touched) that occur as a result of interactions between consumers and employees or other things provided by service providers intended to solve consumer problems" Quality of service consists of two types, namely internal service quality and external service quality.

\subsection{Review of Previous Research}

The results of research studies conducted are:

Asmini *, I Nyoman Sutama, Wahyu Haryadi, Rosydah Rachman in their article entitled " Business Cycle Management as a Base for Post Covid Business Opportunities - 19: A Community Economic Recovery Strategy " Management Study Program, Faculty of Economics \& Management, Samawa University, Sumbawa Besar, Indonesia * E-Mail: Asminifem@Gmail.Com Received: April 29, 2020; Accepted: May 12, 2020; Published: May 19, 2020 .

Ika Fitriyani Samawa University, Nining Sudiyarti Samawa University, M. Nur Fietroh, Sumbawa University of Technology in her research entitled "Post-19 Business Pandemic Business Management Strategy" This research is that SMEs are required to have good knowledge management and absorption to improve business performance.

Mochamad Nurhadi (2015) in his journal entitled "Information Technology Management Audit in Higher Education" the result of the research is the IT management audit process using the eight ZEN Smart Campus frameworks is that Information Technology governance of tertiary institutions as a whole is at level 3 (define process).

Devi Fitrianah and Yudho Giri Sucahyo (2018) in their journal entitled "Information Systems Audit / Information Technology with Cobit Framework for Evaluation of Information Technology Management at Xyz University" with the results of these studies are the findings obtained from testing the effectiveness of controls and test results on output control. In providing recommendations, it is divided into three achievement periods, namely short-term recommendations relating to things that must be immediately carried out by XYZ University so that existing IT processes are still running well. For the medium-term recommendations, classification is based on strategic planning in the IT unit, while for long-term recommendations, recommendations are given relating to University policies at the level of the organization's policies. 


\section{CONCEPTUAL FRAMEWORK}

\subsection{Conceptual Framework}

Technology is the way in which we use science to solve practical problems. While the understanding of information itself is facts or anything that can be used as input in producing information.

\section{1.2 Operational Research}

This research has operational activities, outputs, outcomes and impacts. Implementation began of collecting data through observation college (PT) K eagamaan Islam in East Java.

\section{Research methods}

4. Type of Research

This research is a method of qualitative research

\subsection{Research Approach}

The approach used in this research is Descriptive Analysis through Case Studies .

\section{4 . 3 Research Population}

All business units of Islamic Religious Higher Education Institutions in East Java such as UIN Sunan Ampel Surabaya and UIN Malik Ibrahim Malang.

\section{4 Research Samples}

Determination of the sample in this study did (Purposive Sample). intended to solicit as much information as possible from a variety of sources consisting of business center employees, students, employees who are spread out at the university's Business Center Units, and others at the Religious College in East Java .

\subsection{Types of Data}

The type of data used in this study is qualitative data. As for the data sources collected and used in this study are primary and secondary data. The type of data in this study consists of Audio and Video Records with interviews with informants or data sources, Field Notes, Documentation and Photos / Pictures

\subsection{Data Collection Techniques}

In this study there are several types of collection used by the writer, namely Observation, Interview, and Documentation

\section{4 . 7 Data Analysis Techniques}

The data analysis technique in this research is to use a Qualitative descriptive method, according to Miles and Huberman (1992) that descriptive analysis through three channels namely Data reduction, Data display, and Conclusion drawing / verification

\section{8 Checking Data Validity}

Checking the validity of the data used four inspection techniques, namely:

1) The degree of confidence (Credibility), 2) Keteralihan ( T ransferability), 3) Dependence (dependability), and 4) confirmability 


\section{RESULTS AND DISCUSSION}

The results of the study explained that the integrated online system model of Higher Education during Covid-19 can provide improvement and development of good business sustainability by implementing the strengthening of integrated online transaction systems such as revamping management in business services, marketing, human resources, finance and operations as strategic steps to create an efficient and effective business presence.

\subsection{Results of data collection}

Interviews were conducted to find out sharing life experiences with a worker in the business unit of the UIN Sunan ampel Surabaya campus. As is well known, airplane and umroh ticket sellers play an important role in serving travel tickets for field workers, namely lecturers and campus employees and the general public. Because it makes it easy for them to book travel tickets so they do not need to leave the house and avoid contracting the Covid 19 virus. In addition, exploration will be carried out related to the continuity of campus business ventures in the middle of the Covid pandemic19. With the source we chose was a ticket service worker and Umrah service at the business center campus of UIN Sunan Ampel Surabaya, which is located on Ahmad Yani Rubayaa Street 117. He was named Ms. Merlin Apriliyanti .

Name: Merlin Aprilyanti

Type of business : Business ticket and Umrah service

Campus Address: Jalan Ahmad Yani 117 Surabaya

Ru mah address : Perumahan Jaya Maspion Permata Blok A4 No. 41 Bang Bangang Bang

Phone / mobile number: 082142909698

Email: konclen2016@yahoo.co.id

It takes time when the method is carried out on:

day: Monday

date: 1 June 52020

at: 13:00 - 15:30 WIB

It was held at Sunan Ampel State Islamic University in Surabaya, in front of the East Java Regional Police, Jalan Ahmad Yani 117 Surabaya with an interviewer: Ilham

And the results of the interview as follows:

Interviewer: Since when did you work in the business unit of the University of UIN Surabaya?

Worker : 2015

Interviewer: What type of business is here?

Worker : Sale of airplane tickets and Umrah travel

Interviewer: Do you sell on campus or other places?

Workers : at UIN and online

Interviewer: Who are your customers?

Workers : Mrs. Lecturers, employees and students and the general public

Interviewer: Are you worried about covid-19 virus transmission?

Worker : very worried

Interviewer: Are there any business opportunities for you to continue doing business in the midst of the Covid pandemic19?

Pekarja : can run even though income is somewhat reduced because the campus is closed just stay online

Interviewer: Is your creative effort in the success of your campus business venture in the midst of Corona Covid19?

Worker : offine cannot and only online by uploading interesting adverts and the price is relatively cheaper than the market. 
Interviewer: What is the ideal form you want in your business during Pandem i Covid19?

Worker : quality of service is paramount

Interviewer: Have you used an online business during a pandemic

Worker : already

Interviewer: How does Work From Home impact your business?

Worker : income is somewhat reduced but still must be grateful

Interviewer: What is your opinion of government regulations regarding the implementation of Work From

Home?

Workers : very nice and supportive due to the good of society together

Interviewer: How do you get around / respond to the impact of work from home on the work of the campus business venture?

Worker : be patient and keep selling online as much as you can

Interviewer: Are there changes in your work behavior before and after this work from home?

Worker : yes

Interviewer: Are there changes in your consumer behavior before and after this work from home?

Worker : not as usual because the ticket and goods just send a package

Interviewer: What is your relationship with the customer?

Workers: build relationships with them and provide information services that will continue for as long as andemi covid19.

Interviewer: What changes have occurred to your business?

Worker : can sell at the office again by maintaining the health protocol

Interviewer: What strategies did you use to maintain and / or increase your business during the COVID-19 pandemic?

Workers : diligently uploading campus business products in FB, IG, Wa and other social services with attractive price offers and discounts.

Interviewer: Can Work From Home all work effort targets be maximized? And what are your hopes for the future?

Worker: not optimal because we cannot be free in selling limited space for marketing because the leadership policy has been determined

Interviewer: What critical problems are faced by campus business today?

Workers : online system services, shipping and promotions that have not been maximized

Interviewer: If the target is not maximal yet, how do you anticipate it?

Workers : often attract consumers with attractive promos and use an integrated online service

system that makes it easy in all transaction processes .

Interviewer: what does the business unit do to attract the attention of customers?

Workers: Provide promotions that can make them interested.

Interviewer: Does your campus business venture use internet technology to market its business products?

Worker: yes

Interviewer: What was the sales strategy during the covid pandemic?

Worker: by offering goods or products online and through existing social media.

Interviewer: How did your pen selling system with its online?

Worker : Thank God it's good

Interviewer: are you afraid of doing business during the pandemic covid19?

Worker: Fear, yes, but afraid not to overdo it and use health protocols

Interviewer: What are the obstacles when you sell online?

Worker : the online system is very slow and the transaction process is still not comfortable to use and tends to be complicated

Interviewer: how to check the stock of goods, whether online? 
Worker: yes, we do it online, because there is a real time system that can check the stock of goods, the performance and performance of activities in all business units

Interviewer: do you trade directly or online?

Worker: we do online transactions, but sometimes directly when the user is near the office.

Interviewer: if the transaction is online, means the ticket and purchase receipt are sent?

Workers: yes, we send them directly via motorbike or JNE and TIKI.

Interviewer: What is the ease of selling online?

Worker : more advertisements to attract consumers

Interviewer: If the target is not maximal yet, how do you anticipate it?

Workers : advertise more in selling, disciplined, innovative, providing services and good performance .

\section{2 Respect and Strengthen Business Relations with Customers}

It is important to respect the relationship and support of the Business Unit to customers in the current time. These weeks, the customer's email or smartphone notifications will be flooded with updates from Corona Virus. Both from the company where they work or their favorite online shop. For this reason, do not exploit the crisis into an exaggerated opportunity. Use language that is more polite and try to be closer to how they feel. For example, Business Units can send emails by making them private and as short as possible with the core message "We are here to support you. Tell us how we can help you. "In essence, keep strengthening the business unit's relationship by asking how they are doing, but don't overdo it because the business still wants to respect customers .

\section{3 Create the Right Sales Promotion}

This is the right time to strengthen the value of the products that the Business Unit sells. If the Business Unit can develop sales promotions that meet customer needs in the midst of the Corona Virus crisis, by itself, customers will come alone to the business unit . It is better to use digital media when doing promotions because customers spend more time and activities at home. More time spent viewing smartphones or watching TV than usual days. For example, Business Units can make a "buy-now" promotion, or push notification on a customer's smartphone with the words "sending a great promotion to you." or the Business Unit can also send attractive offers to their emails .

\section{4. Creative ways and sales strategies}

In addition to the promotions that the Business Unit uses, create creative sales strategies and strategies. By making a regular customer to see how the Business Unit presented the product U nit College of Business Enterprises. Whether through sad, funny or unique videos, through funny memes, through interesting $e$ - mails and various other ways that are adjusted to the target market of Business Unit products . Different targets, different ways to approach them. For example, Business Units can make unique videos with funny stories. Business units do not need to market their products explicitly. Simply create a unique story, funny and interesting so that customers always want to watch video sales business unit of each Business Unit mem posting on social media or other media.

\section{5 Don't Panic and Don't Stop Selling}

Avoid panic over the Corona Virus pandemic and stop assuming that the Business Unit business will soon go bankrupt due to a decline in sales. Many businesses are on the verge of panic because of the Corona Virus issues out there. Business Units still have to sell U University Business Business products and find prospective customers in various ways that can attract customers to 
continue to buy U University Business Business products . Life might not be completely normal again. So, look for ways for Business Units to adapt and stay in business. After the Business Unit learns an effective sales strategy during the Corona Virus pandemic. The Business Unit should also begin to pay attention to the accounting of business colleges. Moreover, by considering what sales strategies will be carried out, the Business Unit must also continue to look at the business unit's financial condition . For this reason, use digital bookkeeping such as Journals, with this automated system that will accelerate all strategies and decisions taken in business.

\section{6 Tips Manage Business Enterprises Higher Education Permanent Prima On COVID-19.}

The Corona Virus Outbreak or COVID-19 is considered to have a significant impact on various lines of life, including economic activity in Indonesia. The perpetrators $U$ nit Business College of Business seeks to anticipate the spread of COVID-19 in the working environment in various ways. One of them, encouraging employees to work at home or work from home and do not need to come to the office. Business owners also experience problems managing finances when the admin of the financial authority is absent. Vice versa, the admin will have difficulty taking financial decisions if the policy maker is not in the office. In the end, business owners have to rack their brains to keep the company's financial condition in good shape without the need to face-to-face and worry about COVID-19. To overcome the problem of coordination, businesses can carry out a number of financial management strategies without meeting physically. The following are as quoted by Jurnal by Mekari .

\section{7 Send Invoices Without Meeting Physical}

In the current situation, businesses are vulnerable to billing or payment directly to business partners. The reason is, it can increase the risk of COVID-19. However, businesses have the option to easily create billing or payment statement documents. Invoices (invoices) can be sent or received automatically by email as official notifications to business partners to carry out transactions without the need to physically meet customers. If you use Journal online accounting software, you will find it easy to create invoices, complete with 11 different professional designs according to the company's business needs. Of course accompanied by details of the number of goods / services, unit prices, and total prices, as well as the date of purchase in the invoice. In addition, the Journal is also able to save time because the Business Unit will get an immediate notification when there is a late invoice payment.

\section{8 Perform Banking Transactions via Online}

In the business process, business actors cannot be separated from banking transaction activities. To avoid the risk of getting Corona Virus in public spaces, the Business Unit should avoid visiting banking branches directly and preferring transactions online. Through the Cashlink feature in Journals, Business Units can automatically reconcile banks without the hassle of visiting physical offices. The journal will display a summary of bank reconciliation on all cash and bank accounts, as well as changes in cash and bank balances that have not been recorded. You do this by matching the checking account data and transactions in the Journal on the same page. So, no need to print a checking account again. Data on checking accounts can be entered into the Journal through the bank statement import feature and through direct feeds or automatic data withdrawal by linking the bank with the Business Unit Journal account .

\section{9 Monitor Goods Stock in Multi Remote Warehouses}

The increasingly aggressive Corona Virus spread makes Business Units need to think twice about visiting a business warehouse directly. An alternative step that needs to be taken is to check the status of inventory on a regular basis over long distances. With Journal software, the Business 
Unit can monitor the stock of goods in real time without the need to go to its physical warehouse. Not only calculating the inventory of goods, but also knowing the average buying and selling prices, and informing the availability of stock at a moment's notice. You can get references related to Business Unit product performance, and empty stock notifications. Journals help Business Units import large amounts of inventory data quickly with available spreadsheet templates .

\section{10 Monitor the Financial Performance of Business Units}

For U nit College of Business Enterprises with many business units, check the business conditions in each branch is unavoidable. But the Corona Virus outbreak or COVID-19 is now a real block. To avoid the risk of transmission of the virus, it is better for business owners to refrain from direct inspection, but simply monitor their financial performance remotely. With the 'Consolidated Financial Statements' feature found in Enterprise Journal, customers can create joint reports from several companies that are owned at once. This report will present the financial position and results of operations of the parent company and subsidiaries. Thus, the Business Unit can monitor financial condition without having to go out of the room and approach the subsidiary directly, the risk of Covid can be minimized.

\subsection{Monitor Business Performance in Real Time}

Journal is an online accounting software based on cloud computing ( cloud computing) that allows the Business Unit to monitor business anytime and anywhere. Journals are the right solution for business owners, even those without accounting backgrounds. Through the available features, the Business Unit can carry out various transactions using only a smartphone ( smartphone ) or tablet.

Journal data can be accessed easily and bookkeeping can be done automatically. Not only that, the Business Unit can also provide access to other members to process data according to their duties and functions. Most importantly, business owners can monitor business performance in real time through a mobile application. So, as the perpetrators U nit College of Business Enterprises do not need to worry. Ensure that the Business Unit business continues and is able to survive in the current pandemic conditions. As an online accounting software application, the Journal also supports and is committed to helping meet the challenges of maintaining productivity and economic growth amid demands to reduce mobility to the workplace and public crowds through programs . 


\subsection{Models developed in the Business Business Cycle of PT}

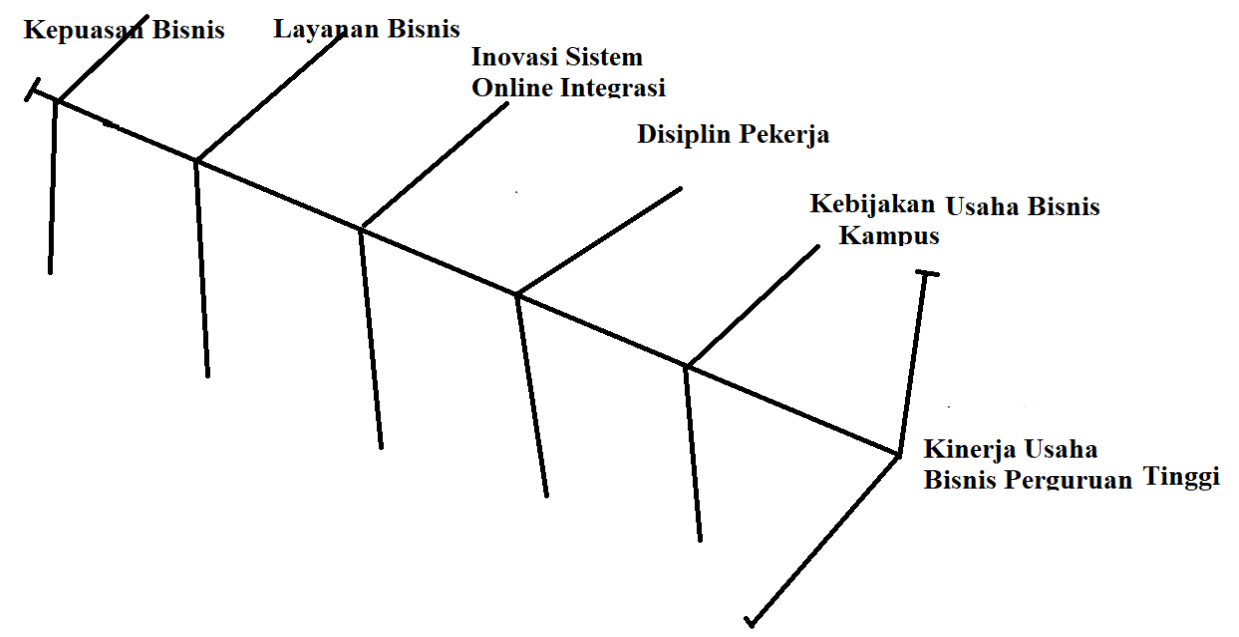

Figure 1 . Model Pe n gembangan Business

From Figure 1 can dijela s right that the stages in the development of business can be started from the determination kebijaka conducted by university leaders and then disseminate to the work in the business units so that they can know all the policies and run a business based on the policy, then pakerja can prepare for work with high discipline, innovation and creativity using information technology and online systems that have been integrated so that more quality and develop business services to get service satisfaction and improve business business performance . 
4:12 konseptual Framework Analysis and Development of B i SNIS

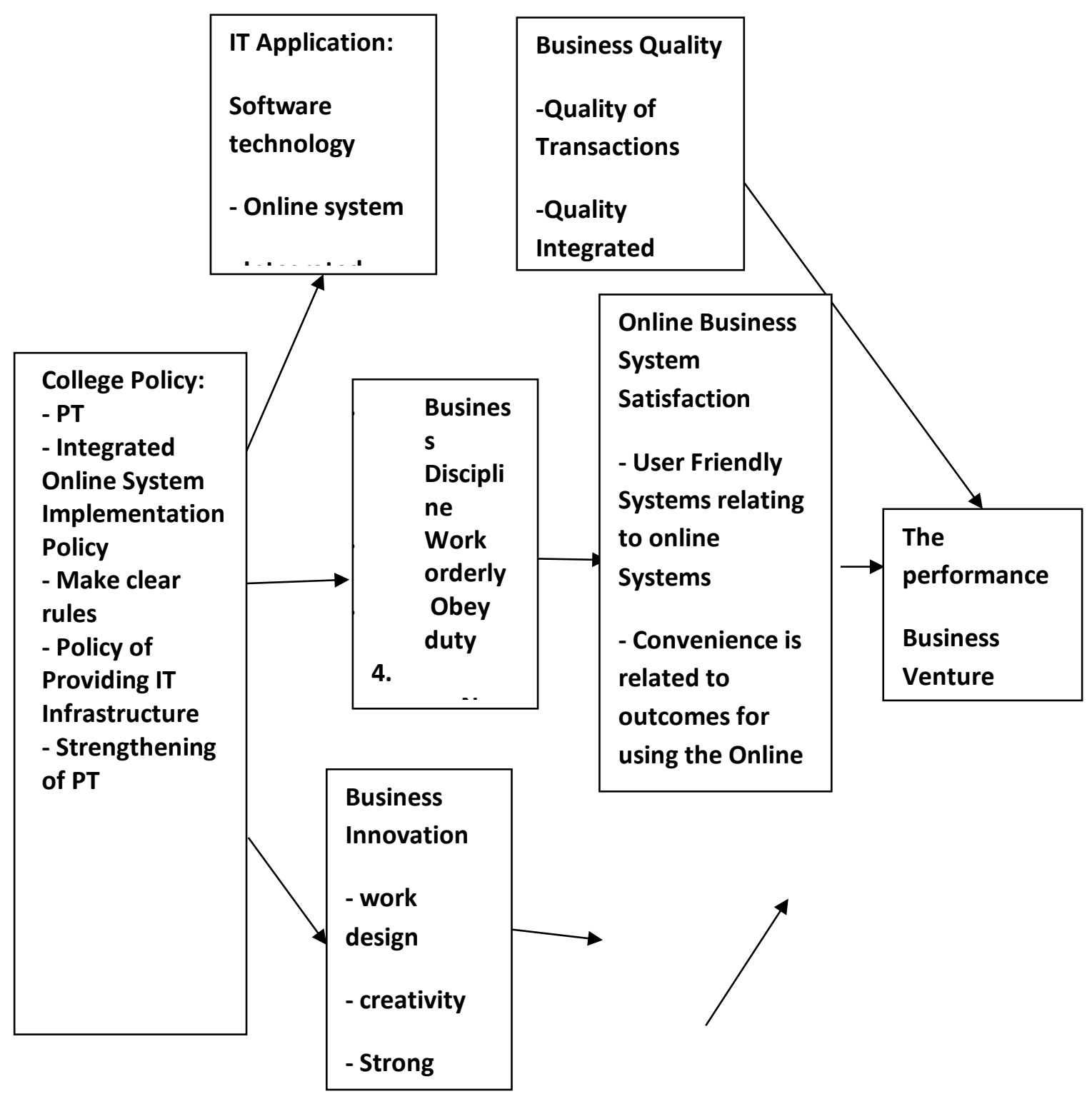

Figure 4 . Concept Framework for Business Unit System Development PT 


\subsection{Findings in the Study}

College that policies related venture businesses will greatly affect how s i stem a business venture that will run. A good policy is a policy that can support all business processes of higher education institutions so that all services, work discipline, integrated online system innovation, and job satisfaction and services become better and service users can feel the convenience of the transaction. If all of that can be done well, the performance of all stakeholders will be more optimal.

\section{Conclusion}

Based on the analyst is and evaluation system model is integrated as $a b$ asis change efforts during Covid-19, can be concluded as follows: With the online system integrated with the planning and organization of the system of business the business can describe the classification of the various implementation activities of services online business venture in order to facilitate all form of business transaction processes quickly, effectively and efficiently during Covid19. System integration of online ie business opportunities using technology that can deliver greater value for the business of the college's ehingga college business can be developed and can be maintained as well as helping people to meet their needs and facilitate online transactions.

\section{Suggestion} following:

Based on the study results and conclusions outlined above, the Pen eliti recommend the (1) Overall, for Higher Education, it is expected that in running a business a business needs an integrated online system and preparing policies that support all changes to the system integration online, as a unitary system capable of serving various forms of business transactions during the Covid-19 pandemic so that it can become a college business unit recovery strategy .

(2) It is expected that the public and business people can prepare themselves to be able to use the online system and carry out online transaction processing during the Covid-19 pandemic .

(3) For other researchers, the results of this study can be used as a reference to be developed by examining other variables

\section{BIBLIOGRAPHY}

1. Assumes reproductive number greater than two. A number of recent publications assert this. See, for example, Zhang, S., Diao, M., Yu, W., Pei, L., Lin, Z., and Chen, D., "Estimation of the reproductive number of coronavirus novels (COVID_19) and the probable outbreak size on the Diamond Princess cruise ship: A data-driven analysis, "National Center for Biotechnology Information, February 20, 2020, pubmed.gov.

2. Wu Zunyou and Jennifer M. McCoogan, "Characteristics of and important lessons from the coronavirus disease 2019 (COVID_19) outbreak in China," JAMA: Journal of the American Medical Association, February 2020, jamanetwork.com.

3. This is how coronavirus can affect the travel and tourism industry [Internet]. World Economic Forum. [cited $2020 \quad$ Mar 20$]$ Available from: https://www.weforum.org/agenda/2020/03/world-travel-coronavirus-covid19-jobspandemic-tourism-aviation/ Google Scholar

4. 5 things supermarkets want you to know during the pandemic COVID-19| World Economic Forum [Internet]. [cited $2020 \quad$ Mar 23$]$ Available from: https://www.weforum.org/agenda/2020/03/supermarkets-grocery-coronavirus-covid19supply/ Google Scholar 
5. from: https://realtime.rediff.com/news/india/Prices-of-agricultural-commodities-drop-20post- COVID19outbreak / 955078599584b749? src = interim alsoreadimage Google Scholar 6. from: https://realtime.rediff.com/news/india/Prices-of-agricultural-commodities-drop-20post-COVID19-outbreak/955078599584b749?src=interim alsoreadimage Google Scholar 7. COVID-19 is Coming for the Chemical Industry in 2020, BASF Frets IndustryWeek [Internet]. [cited 2020 Mar 20] Available from: https://www.industryweek.com/supplychain/planning-forecasting/article/21125045/covid19-is-coming-for-the-chemical-industry-in2020-basf-frets Google Scholar

8. Knieps S. Will COVID-19 turn Germany's export-oriented economy into a weakness? [Internet]. www.euractiv.com . 2020 [cited 2020 Mar 23]. Available from: https://www.euractiv.com/section/economy-jobs/news/will-covid-19-turn-germanysexport-oriented-economy-into-a-weakness/ Google Scholar

9. Guidance for schools, childcare providers, colleges and local authorities in England on maintaining educational provision [Internet]. GOV.UK. [cited 2020 Mar 20] Available from: https://www.gov.uk/government/publications/coronavirus-covid-19-maintainingeducational-provision/guidance-for-schools-colleges-and-local-authorities-on-maintainingeducational-provision Google Scholar

10. https://plus.google.com/+UNESCO. COVID-19 Educational Disruption and Response [Internet]. UNESCO. $2020 \quad$ [cited $2020 \quad$ Mar 20]. Available from: https://en.unesco.org/themes/education-emergencies/coronavirus-school-closures Google $\underline{\text { Scholar }}$

11. MR Keogh-Brown, S. Wren-Lewis, WJ Edmunds, P. Beutels, RD Smith The possible macroeconomic impact on the UK of an influenza pandemic Health Econ, 19 (11) (2010), pp. 1345-1360 CrossRef View Record in Google Scholar Scopus

12. Europe's economic rescue packages worth combined $€ 1.7$ tn World news | The Guardian [Internet]. [cited $2020 \quad$ Mar 20$]$ Available from: https://www.theguardian.com/world/2020/mar/19/europes-economic-rescue-packagesworth-combined-17tn Google Scholar

13. Kurzarbeitergeld: Übersicht - Bundesagentur für Arbeit [Internet]. [cited 2020 Mar 20] Available from: https://www.arbeitsagentur.de/unternehmen/finanziell/kurzarbeitergelduebersicht-kurzarbeitergeldformen Google Scholar

14. Smialek J. Fed Official Says Central Bankers Are Aligned in Coronavirus Response. The New York Times [Internet]. 2020 Mar 5 [cited 2020 Mar 20]; Available from: https://www.nytimes.com/2020/03/05/business/economy/fed-rate-cutcoronavirus.html Google Scholar

15. Tanne JH, Hayasaki E, Zastrow M, Pulla P, Smith P, Rada AG. Covid-19: how doctors and healthcare systems are tackling coronavirus worldwide. BMJ [Internet]. 2020 Mar 18 [cited 2020 Mar 20]; 368. Available from: https://www.bmj.com/content/368/bmj.m1090 Google Scholar 16. Net H. MGM Resorts International Statement On Temporary Closure Of Las Vegas Properties [Internet]. Hospitality Net. [cited 2020 Mar 20] Available from: https://www.hospitalitynet.org/news/4097568.html Google Scholar

17. Amy European Tourism Sector Demands Urgent Supportive Measures to Reduce Devastating Impacts of COVID-19 [Internet]. Hotel-Online. [cited 2020 Mar 20] Available from: https://www.hotel-online.com/press releases/release/european-tourism-sector-demandsurgent-supportive-measures-to-reduce-devastating-impact-of-covid-19/ Google Scholar 18. Regalado, "Blood tests show 14\% of people are now immune to COVID_19 in one town in Germany," MIT Technology Review, April 9, 2020, technologyreview.com.

19. "COVID_19 therapies and vaccines: Clinical," Biocentury, biocentury.com. 
20. Pickford J. Coronavirus hit the UK property market as viewings dry up [Internet]. 2020 [cited 2020 Mar 20]. Available from: https://www.ft.com/content/e30ccb84-6799-11ea-800dda70cff6e4d3 Google Scholar

21. Jack S. Online shopping website Ocado suspends service. BBC News [Internet]. 2020 Mar 18 [cited 2020 Mar 23]; Available from: https://www.bbc.com/news/business- 51941987 Google Scholar

22. Kent E. Coronavirus outbreak forces cancellation of multiple esports events [Internet]. Eurogamer. $2020 \quad$ [cited $2020 \quad$ Apr $\quad 8]$. Available rom: https://www.eurogamer.net/articles/2020-01-30-coronavirus-outbreak-forces-cancellationof-multiple-esports-events Google Scholar .

23. Brown et.al. 2001. Capacity development in the Civic Education system organization at PTM

24. Connolly, Thomas and Begg, Carolyn. 2010. Database Systems: A Practical Approach to Design, Implementation, and Management, Fifth Edition. Pearson Education, Boston.

25. Dennis, Alan; Wixom, Haley Barbara: \& Tegarden, David. 2012. Systems Analysis and Design with UML Version 2.0: An Object-Oriented Approach. Second Edition. United States of America: John Wiley \& Sons, Inc.

26. Fauziah. 2010. Introduction to Information Technology. Bandung. Muara Indah. Gie, Liang. 2000. Modern Office Administration. Yogyakarta: Liberty.

27. Fauzandkk.2015. Administration System Management Management Archives Sign In And Letter Out Web Based. Indonesian Journal on Networking and Security, Volume 4, Number 3. Ponorogo Muhammadiyah University Ponorogo.

28. Fitrianah, Devi and Sucahyo, Yudho Giri. 2008. "Information System / Information Technology Audit With COBIT Framework for Evaluation of Information Technology Management". Journal of Information Systems UI. http://jurnal.mti.cs.ui.ac.id/ index.php / jsi / article / viewFile / 243/69. Downloaded September 202013.

29. Godfrey, Sally. 2008. "The Characteristics of the Maturity levels", http://commons.wikimedia.org/ wiki / File: Characteristics_of_Capability_Maturit y_Model.svg. Accessed September 2, 2013

30. HAR Tilaar. 2002. Social Change and Education Introduction to Transformative Pedagogic for Indonesia. Jakarta: Grasindo.

31. Hall, James A. 2011. "Information Technology Auditing and Assurance", Third Edition, Nelson Education Ltd, Canada.

32. IT Governance Institute. 2007. "COBIT 4.1 Framework, Control Objectives, Management Guidelines, Maturity Models". Rolling Meadows, USA: Author.

33. IT Governance Institute. 2008. "Aligning COBIT 4.1, ITIL V3 and ISO / IEC 27002 for Business Benefits, A Management Briefing from ITGI and OGC". Rolling Meadows, USA: Author.

34. Kristanto, Harianto. 2004. Database Concepts and Design. Yogyakarta: Andi Ladjamudin, Albahra. 2005. Analysis and Design of Information Systems. Yogyakarta: Graha Science

35. Kadir, Abdul. 2014. Introduction of Information Systems. Yogyakarta: CV Andi Offset

36. Kendall, E. Kenneth; \& Kendall, E. Julie. 2011. Systems Analysis and Design. Eighth Edition. United States of America: Pearson Education Inc.

37. Laudon, KC, \& Laudon, JP 2012. Management information systems: organizations and technology in the networked enterprise (Sixth ed.).

38. Mutyarini, K., Sembering, J. (2006). Information System Architecture for Higher Education Institutions in Indonesia, Proceedings of KNTI \& K. pp102- 107.

39. Higher Education Council. 2002. Guidebook for Civic Education Development Workshop at PTM. Yogyakarta: 
40. Munandir. 1987. Design of Teaching Systems. Jakarta: Ministry of Education and Culture. Directorate General of Dictation. P2LPTK.

41. Morrison, 2001. organization so that it can respond to an environment that is undergoing continual change Jakarta: Grasindo

42. Milen, 2001 Capacity building consists of phases that are closely related to each other even though they do not have to occur in a linear sequence in Civic Education at PTM

43. McLeod, Jr. Raymond; \& P. Schell, George. 2007. Management Information Systems. Tenth Edition. New Jersey, United States of America: Pearson Prentice Hall.

44. O'Brien, A. James and M. Marakas George, Introduction to Information Systems, 2010. McGraw-Hill Companies, Inc., 1221 Avenue of the Americas, New York.

45. Pressman, Roger S., 2010, Software Engineering: A Practitioner's Approach.

46. Pederiva, Andrea. 2003. "The COBIT Maturity Model in a Vendor Evaluation Case", Information Systems Control Journal, Volume 3. http://www.isaca.org/Journal/Past-Issues/2003/ Volume-3 / Documents / jpdf033-COBITMaturity Model .pdf. Accessed October 25, 2013.

47. Sarno, Riyanarto. 2009. "System and Information Technology Audit", ITS Press, Surabaya. 48. https://kalteng.antaranews.com/berita/389920/prospek-bisnis-online-di-era-pandemi-covid$\underline{19}$ 